\title{
Student-Faculty Interaction in Research Universities: Differences by Student Gender, Race, Social Class, and First-Generation Status
}

\author{
Young K. Kim · Linda J. Sax
}

Received: 12 December 2007 / Published online: 25 February 2009

(C) The Author(s) 2009. This article is published with open access at Springerlink.com

\begin{abstract}
This study examined whether the effects of student-faculty interaction on a range of student outcomes-i.e., college GPA, degree aspiration, integration, critical thinking and communication, cultural appreciation and social awareness, and satisfaction with college experience-vary by student gender, race, social class, and first-generation status. The study utilized data on 58,281 students who participated in the 2006 University of California Undergraduate Experience Survey (UCUES). The findings reveal differences in the frequency of student-faculty interaction across student gender, race, social class and first-generation status, and differences in the effects of student-faculty interaction (i.e., conditional effects) that depended on each of these factors except first-generation status. The findings provide implications for educational practice on how to maximize the educational efficacy of student-faculty interaction by minimizing the gender, race, social class, and first-generation differences associated with it.
\end{abstract}

Keywords Student-faculty interaction - Research university · Conditional effects · Gender $\cdot$ Race $\cdot$ Social class $\cdot$ First-generation

Interacting with faculty-whether in the classroom, the laboratory, office hours, or other venue-is one of the key college experiences associated with student development. Positive and close interactions between undergraduates and their professors precipitate students' favorable educational experiences as well as their greater academic and personal development (Lau 2003; Pascarella and Terenzini 2005). Two higher education studies, Pascarella (1980) and Pascarella and Terenzini (2005), provide a comprehensive and

Y. K. Kim

Office of Research and Planning, Cerritos College, Norwalk, CA, USA

L. J. Sax $(\bowtie)$

Higher Education and Organizational Change, Graduate School of Education \& Information Studies, University of California, Los Angeles, 3335 Moore Hall, Box 951521, Los Angeles,

CA 90095-1521, USA

e-mail: 1sax@ucla.edu 
critical literature review on student-faculty interaction and its relationship with college outcomes. Pascarella (1980) summarizes a number of studies, conducted prior to 1980, on the effects of informal (out-of-class) student-faculty interaction on various college student outcomes that are grouped into five categories: career plans and educational aspirations, satisfaction with college, intellectual and personal development, academic achievement, and college persistence. Based on his intensive analysis of the literature, Pascarella suggests that statistically significant positive associations exist between student contact with faculty and these five categories. He maintains that these associations are valid even after controlling for a broad range of student input characteristics and, in a few studies, other college experiences. In How College Affects Students, Pascarella and Terenzini (2005) reinforce Pascarella's early findings by including formal (in-class) student-faculty interaction, as well as the informal (out-of-class) interaction, and by adding a number of studies from the 1980s through 2000s. In line with Pascarella (1980), they demonstrate that the amount and quality of student-faculty interaction positively affect various student outcomes, including subject matter competence, cognitive skills and intellectual growth, attitudes and values, educational attainment, and career choice and development.

As findings from the two literature reviews suggest, college impact research has continually demonstrated a favorable relationship between student-faculty interaction and a broad range of student educational outcomes (e.g., Astin 1977, 1993; Cabrera et al. 2001; Campbell and Campbell 1997; Endo and Harpel 1982; Ishiyama 2002; Kuh 1995; Kuh and Hu 2001; Lamport 1993; Pascarella 1980, 1985; Pascarella and Terenzini 1976; Strauss and Terenzini 2007; Terenzini et al. 1999; Thompson 2001; Volkwein et al. 1986). In general, the research reveals that more contact between students and faculty, both inside and outside the classroom, enhances college students' development and learning outcomes.

Whereas the majority of research until the 1990s documented the "general" positive effect of faculty contact on educational outcomes utilizing aggregate student samples (i.e., not disaggregated by race, gender, or other factors), a number of recent studies highlight that the effect of student-faculty interaction may be "conditional." Specifically, contrary to a "general" college effect, a "conditional" effect assumes that the same intervention or experience might not have the same impact for all kinds of students (Pascarella 2006). Some studies demonstrate that the impact of student-faculty interaction may differ by student gender (Colbeck et al. 2001; Kezar and Moriarty 2000; Sax et al. 2005), and others reveal differences by race (Cole 2004; Kim 2006; Lundberg and Schreiner 2004). With respect to gender, Sax et al. (2005) found that, compared to female students, male students experienced greater gains in political engagement, social activism, and liberalism resulting from their interactions with faculty. By contrast, the positive effects of student-faculty interaction on the students' sense of physical, emotional, and academic well-being were more evident among females. In regards to conditional effects by race, Kim (2006) shows that student-faculty interaction has a significantly positive effect on White students' educational aspiration, but not on African Americans, Asian Americans, and Latinos. Kim also found that student-faculty interaction has no significant effect on racial tolerance for African American and Latino students, as opposed to a significantly positive effect for White and Asian American students.

These results suggest that the estimation of general effects using combined student samples cannot fully explain the relationship between student-faculty interaction and student educational outcomes. Furthermore, the existence of gender- or race-based conditional effects in student-faculty interaction raises the question about other conditional effects in the college experience. Indeed, Pascarella (2006) argues that broadening our 
notion of diversity regarding the college student populations beyond racial diversity (e.g., diversity of social class, value, or religious views) may improve college impact research.

Another factor which may influence the role played by student-faculty interaction is the type of college attended by students. Undergraduates in small, liberal arts colleges benefit from more frequent interactions with faculty-both in and out of class-while those attending large research universities may have more difficulty gaining access to faculty (Boyer Commission 1998; Kuh and Hu 2001; Kuh and Vesper 1997). Students at large research universities encounter at least two potential challenges to faculty access: first is the large student-faculty ratio which inherently limits opportunity for direct interaction with faculty, and second is an emphasis on research which can focus faculty attention on graduate students at the expense of undergraduates (Astin and Chang 1995). However, an emphasis on research need not come at the expense of undergraduates, as it provides a potentially powerful opportunity for undergraduate learning and engagement.

The current study improves our knowledge base of the conditional effects of studentfaculty interaction by examining different patterns of student-faculty interaction for various types of student subgroups within a large research university system. Specifically, it seeks to answer the questions: (1) How does the frequency of student-faculty interaction vary by student gender, race, social class, and first-generation status ${ }^{1}$ ? (2) How does student satisfaction with faculty contact vary by student gender, race, social class, and firstgeneration status? (3) How does the relationship between student-faculty interaction and student educational outcomes vary by these student characteristics?

\section{Research Framework}

The relationship between student-faculty interaction and student educational outcomes is well explained by various theoretical frameworks (see Astin 1984; Pascarella 1985; Tinto 1987, 1993; Weidman 1989). However, Astin's involvement theory (1984) and I-E-O (Inputs-Environments-Outcomes) framework (1991) are especially relevant, in both a conceptual and a methodological sense, to the current study. Astin's involvement theory stresses "behavioral mechanisms or processes that facilitate student development" (Astin 1984, p. 301). He suggests that students are more likely to learn and develop when they invest more time and energy in meaningful college experiences. Since his involvement concept is clearly operationalized, and also mirrors the "time-on-task" construct, it can be easily and reliably measured by quantitative survey items. Moreover, Astin's I-E-O framework accounts for characteristics that vary both within institutions (e.g., student background characteristics and college experiences) and between institutions (e.g., college environments). The I-E-O framework informs the main analytical approach for this study and it can be expressed as the following equation:

$$
Y=\mathrm{a}+\mathrm{b}_{1} S I+\mathrm{b}_{2} C E n+\mathrm{b}_{3} C E x+\mathrm{b}_{4} S F I+\mathrm{e}
$$

For this model, $Y, S I, C E n, C E x$, and SFI represent the levels of outcome variables, of student input characteristics, of college environments, of college experiences, and of student-faculty interaction, respectively. This framework allows researchers to estimate the unique predictive power of student-faculty interaction on outcome measures, controlling for an extensive set of within- and between-institutional confounding variables.

${ }^{1}$ In this study, first-generation college students refer to those whose parents have not attended college (Billson and Terry 1982). 


\section{Methods}

\section{Data Source and Sample}

The present study used data from the 2006 University of California Undergraduate Experience Survey (UCUES), which is a longitudinal survey of UC undergraduate students administered by the UC Berkeley Office of Student Research and managed by the University of California Office of the President. Included in this study are items from the UCUES Core and the Academic Engagement Module. The Core Items target all UC undergraduates, and gather information on student background characteristics, academic and personal development, academic engagement, satisfaction, and evaluation of the major. The Academic Engagement Module targets a randomly selected $20 \%$ of the students, and collects data on students' college experiences and their perceptions of the university.

The Core Items survey was administered to a pool of 153,457 UC undergraduates, yielding a response rate of $38.0 \%$. Thus, the sample for this study consisted of 58,281 undergraduate students from nine UC campuses who completed 2006 UCUES Core Items. The sample included more female students $(54.1 \%)$ than male students $(45.8 \%)$. Students were primarily from middle-class $(58.8 \%)$ and upper-class $(30.5 \%)$ families, with fewer from lower-class families $(10.8 \%){ }^{2}$ Of the total sample, $19.5 \%$ of students were firstgeneration college students. The racial composition was as follows: $35.1 \%$ White, $3.0 \%$ African American, 38.3\% Asian Americans, 13.9\% Latinos, and 9.7\% other race. The Academic Engagement Module was administered to a pool of 31,012 UC undergraduate students (approximately $20 \%$ of 153,457 students), resulting in a response rate of $38.4 \%$. Thus, the sample was limited to 11,928 students for the statistical analyses in which we used variables drawn from the Academic Engagement Module. ${ }^{3}$

\section{Variables}

\section{Student Outcome Measures}

Since research has demonstrated that student-faculty interaction is linked to a variety of student educational outcomes (Astin 1977, 1993; Pascarella 1980; Pascarella and Terenzini 2005; Sax et al. 2005), this study employed multiple outcome measures. Based on several of the categories of student outcomes used by Pascarella (1980) and Pascarella and Terenzini (2005), this study selected six outcome measures that target academic achievement, educational aspirations, affective response to college, and intellectual and personal development: college GPA (grade point average), degree aspiration, integration, two selfreported gains in skills (critical thinking and social awareness), and satisfaction with overall college experience.

\footnotetext{
2 The social class variable was created from students' self-categorization of their social class on a five-point scale from $1=$ "low-income or poor" to $5=$ "wealthy." The three social class groupings used in this study were created by collapsing the original variable into "lower-class" (includes low-income or poor and working class), "middle-class (includes middle-class), and "upper class" (includes upper-middle, professional-middle, and wealthy).

3 The variables drawn from the Academic Engagement Module include communicating with faculty by email or in person, talking with faculty outside of class about course material, and interacting with faculty during lecture class sessions.
} 
All outcome measures were collected on the 2006 UCUES Core (Appendix Table 5 details specific survey items for each outcome measure and descriptive statistics for the full sample). College GPA and degree aspiration were measured by students' transcript-based undergraduate GPA (i.e., GPA reported in UC system student records) and their selfreported highest degree planned in Spring 2006, respectively. The other four outcomes were assessed via composite measures developed either by the authors or the Center for Studies in Higher Education (CSHE) at UC Berkeley. Using principal component factoring and Varimax rotation methods, we developed two factor scales which measure students' integration and satisfaction. Integration reflects the degree in which a student shares the normative attitudes and values of peers and faculty in college (Pascarella and Terenzini 2005). In this study, the factor scale that measures integration was constructed using two items concerning students' perception of belonging at their campus (Cronbach's alpha $=.83$ ). The composite measure of satisfaction was created by combining student academic and social satisfaction (Cronbach's alpha $=.85$ ). To compute the factor scale scores, we summed scores of each item and divided by the number of items in the composite measure. Two self-reported gains in skills were assessed using two pre-developed composite measures by the Center for Studies in Higher Education (CSHE) at UC Berkeley. Gains in Critical Thinking and Communication reflects self-reported gains since entering college in a variety of skills, including critical thinking, communication, leadership, writing, and library search skills (Cronbach's alpha =.91). Gains in Cultural Appreciation and Social Awareness reflects self-reported gains since entering college in students' appreciation of diversity, the fine arts, and social responsibility (Cronbach's alpha $=.87$ ). The distributions of responses on the six outcome measures were approximately normal, showing skewness of -.91 to .56 .

\section{Student-Faculty Interaction Measures}

This study used two composite measures to gauge the frequency with which students interact with faculty. A factor scale, research-related student-faculty interaction, comprises three items concerning the frequency with which students assisted faculty with research as a volunteer, for course credit, or for pay (Cronbach's alpha $=.60$ ). The other factor scale, course-related student-faculty interaction, consists of three other items: talking with faculty outside of class about course material, communicating with faculty by email or in person, and interacting with faculty during lecture class sessions (Cronbach's alpha $=.83$ ). The two student-faculty interaction measures were generated through exploratory factor analyses, using principal component factoring and Varimax rotation methods. We also computed the composite measure scores by summing scores of each item and dividing by the number of items in the factor scale (see Appendix Table 6).

Furthermore, to examine students' perception of their interaction with faculty across different student subgroups, the current study employed two additional variables regarding student satisfaction with faculty contact: satisfaction with advising by faculty on academic matters and satisfaction with access to faculty outside of class. These satisfaction variables were used for cross-tabulation analyses only, not for regression analyses. In most college impact literature, students' satisfaction with college experience has been considered as a student "outcome" of higher education, rather than college "experience" (Astin 1991, 1993; Pascarella 1980; Pascarella and Terenzini 2005). Thus, in this study, the two variables that capture students' level of satisfaction with faculty interaction were not entered into regressions as independent variables. 


\section{Control Variables}

Drawn from both the Core Items and Academic Engagement Module, six blocks of control variables include the following: (1) Student demographic characteristics, (2) Initial freshman year experiences, (3) Institutional characteristics, (4) Student major field, (5) Major field climate, and (6) College Experiences (refer to Appendix Table 7 for a complete list of coding schemes and descriptive statistics for control variables). Of the six blocks, the first two variable blocks correspond to student input characteristics. The college impact literature demonstrates that educational assessments will be biased unless the effects of student input characteristics are controlled (Astin 1977, 1991, 1993; Pascarella and Terenzini 2005). The input variables in this study include both student background characteristics (gender, race, age, parent's education level and income, year when a student was born or came to US, and language heritage) and freshman year experiences (transfer status and term of entry). The following three blocks—institutional characteristics, student major field, and major field climate-reflect college environments. Based on the findings from research that students' field of study (Astin 1993; Astin and Holland 1961; Smart et al. 2000) and perceptions of campus cultural environments (Ancis et al. 2000; Colbeck et al. 2001; Hurtado 1992; Hurtado et al. 1996) may significantly affect their college experiences and outcomes, this study employed students' major fields and major field climate as part of college environment variables along with institutional characteristics. The last block of control variables includes college experiences and captures a student's direct experience and involvement during college. Based on his rigorous literature review, Pascarella (1980) suggests that researchers should take into account both students' pre-college characteristics and other college experiences when examining the effects of student-faculty interaction on college outcomes. Without controlling for other college experiences, Pascarella maintains, it is difficult to assess the unique contribution of student-faculty interaction on student outcomes. Indeed, Kuh and $\mathrm{Hu}$ (2001) reported that positive effects of faculty contact on students' satisfaction and gains were mediated by other college experiences (e.g., hours spent on school work). Controlling for an extensive set of confounding variables in regression analyses, this study could estimate the unique predictive power of studentfaculty interaction on college student outcomes.

\section{Analyses}

First, cross-tabulations were conducted to compare the frequency of student-faculty interaction as well as level of student satisfaction with faculty contact among different student subgroups. Moreover, Chi-square statistics were also computed to detect whether the differences observed are statistically significant. Furthermore, blocked regression analyses were conducted separately for each student subgroup to examine conditional effects of student-faculty interaction by the following student characteristics: gender, race, social class, and first-generation status. Since each conditional effect was examined independently, four sets of separate regression models were developed. For example, to determine gender differences, initial exploratory separate regressions were run for male and female students, using "forward entry," such that only variables that were significant at $p<.01$ would enter the regression equation. From these analyses, we could isolate variables that entered the regression for either males or females. These variables were then "force-entered" identically in separate regressions for each gender. The same approach was repeated for the other student characteristics (i.e., race, social class, first-generation 
status). Since this study is interested in determining if the effects of student-faculty interaction make a unique contribution over the effects of other independent variables, a student-faculty interaction measure (either research-related or course-related interaction) entered each regression model in the seventh block after controlling for all other six independent variable blocks. For all regression models developed by this study, tolerance levels ranged from .50 to .99 (i.e., VIF ranged from 1.01 to 2.00), which indicate low multicollinearity and stability of regression coefficients (Garson 2008). Finally, to examine whether the effects of student-faculty interaction are significantly different between student subgroups, the magnitude of the unstandardized regression coefficients were compared via $t$-tests.

\section{Results}

Differences in the Frequency of Student-Faculty Interaction by Student Characteristics

We first tested how the frequency of student-faculty interaction varies by student gender, race, social class, and first-generation status. Compiling the results from four sets of crosstabulations, Table 1 displays the frequency of different types of faculty interaction experienced by various kinds of student subgroups. Overall, the differences in the frequency of faculty contact based on each student characteristic were modest or small, but statistically significant on certain forms of student-faculty interaction.

Gender differences were statistically significant on five of six different forms of student-faculty interaction. For research-related faculty contact, male students were more likely than female students to assist faculty with research as a volunteer or for pay, whereas females were more likely than males to assist faculty with research for course credit. For course-related faculty contact, female students reported more frequent communication with faculty by email or in person than males, while males demonstrated more frequent interaction with faculty during lecture class sessions than females. The frequency of faculty contact also significantly varied on most types of student-faculty interaction across student racial subgroups. Asian American students were more likely than African American, Latino, and White students to assist faculty with research as a volunteer or for course credit, but they were less likely than other racial groups to have talked, communicated, or interacted with faculty regarding course-related matters. Conversely, African American students reported the greatest frequency of talking, communicating, or interacting with faculty, whereas they demonstrated the lowest frequency of assisting faculty with research as a volunteer or for course credit.

Along with gender and race differences, the results show several differences by students' social class and first-generation status. Students from upper-class families were more likely than students from lower- or middle-class families to assist faculty with research for course credit, communicate with faculty by email or in person, and interacted with faculty during lecture class sessions. In contrast, students from lower-class families were more likely than their counterparts to assisted faculty with research for pay. Differences in the frequency of faculty contact based on a student's first-generation status were statistically significant on three types of student-faculty interaction. Students whose parents attended college were more likely than students whose parents have not attended college to assist faculty with research for course credit, communicate with faculty by email or in person, and interact with faculty during lecture class sessions. 
Table 1 Frequency of student-faculty interaction by student subgroups

\begin{tabular}{|c|c|c|c|c|c|}
\hline \multirow[t]{2}{*}{ Type of interaction } & & \multicolumn{4}{|l|}{ Gender } \\
\hline & & Male & \multicolumn{2}{|l|}{ Female } & Chi-square \\
\hline \multicolumn{6}{|l|}{ Research-related student-faculty interaction } \\
\hline Students assisted faculty research as a volunteer & & 17.1 & \multicolumn{2}{|l|}{15.5} & $12.996 * *$ \\
\hline Students assisted faculty research for course credit & & 18.8 & \multicolumn{2}{|l|}{20.4} & $11.739 *$ \\
\hline Students assisted faculty research for pay & & 12.7 & \multicolumn{2}{|l|}{10.2} & $47.232 * *$ \\
\hline \multicolumn{6}{|l|}{ Course-related student-faculty interaction } \\
\hline $\begin{array}{l}\text { Students frequently }{ }^{\mathrm{a}} \text { talked with faculty outside } \\
\text { of class about course material }\end{array}$ & & 20.3 & \multicolumn{2}{|l|}{18.7} & 4.500 \\
\hline $\begin{array}{l}\text { Students frequently }{ }^{\mathrm{a}} \text { communicated with faculty } \\
\text { by email or in person }\end{array}$ & & 33.9 & \multicolumn{2}{|l|}{38.2} & $35.131 * *$ \\
\hline $\begin{array}{l}\text { Students frequently }{ }^{\mathrm{a}} \text { interacted with faculty } \\
\text { during lecture class sessions }\end{array}$ & & 22.5 & \multicolumn{2}{|l|}{19.9} & $41.860 * *$ \\
\hline \multirow[t]{2}{*}{ Type of interaction } & \multicolumn{5}{|l|}{ Race } \\
\hline & $\begin{array}{l}\text { African } \\
\text { American }\end{array}$ & Latino & $\begin{array}{l}\text { Asian } \\
\text { American }\end{array}$ & White & Chi-square \\
\hline \multicolumn{6}{|l|}{ Research-related student-faculty interaction } \\
\hline Students assisted faculty research as a volunteer & 12.6 & 15.3 & 17.4 & 15.4 & $46.451 * *$ \\
\hline Students assisted faculty research for course credit & 16.8 & 18.9 & 20.9 & 18.8 & $30.349 * *$ \\
\hline Students assisted faculty research for pay & 12.5 & 11.3 & 11.5 & 10.9 & 3.815 \\
\hline \multicolumn{6}{|l|}{ Course-related student-faculty interaction } \\
\hline $\begin{array}{l}\text { Students frequently }{ }^{\mathrm{a}} \text { talked with faculty outside } \\
\text { of class about course material }\end{array}$ & 32.8 & 23.2 & 14.2 & 21.9 & $204.603 * *$ \\
\hline $\begin{array}{l}\text { Students frequently }{ }^{\mathrm{a}} \text { communicated with faculty } \\
\text { by email or in person }\end{array}$ & 52.2 & 41.8 & 28.3 & 41.5 & $310.192 * *$ \\
\hline $\begin{array}{l}\text { Students frequently interacted with faculty during } \\
\text { lecture class sessions }\end{array}$ & 36.0 & 23.2 & 12.6 & 27.7 & $540.864 * *$ \\
\hline
\end{tabular}

Type of interaction

Social class

Lower-class Middle-class Upper-class Chi-square

Research-related student-faculty interaction

\begin{tabular}{|c|c|c|c|c|}
\hline Students assisted faculty research as a volunteer & 17.5 & 16.6 & 17.8 & 6.012 \\
\hline Students assisted faculty research for course credit & 20.0 & 20.0 & 23.0 & $31.895 * *$ \\
\hline Students assisted faculty research for pay & 13.8 & 11.4 & 12.0 & $15.373 * *$ \\
\hline \multicolumn{5}{|l|}{ urse-related student-faculty interaction } \\
\hline $\begin{array}{l}\text { Students frequently }{ }^{\mathrm{a}} \text { talked with faculty outside } \\
\text { of class about course material }\end{array}$ & 20.4 & 18.6 & 20.2 & 12.092 \\
\hline $\begin{array}{l}\text { Students frequently }{ }^{\mathrm{a}} \text { communicated with faculty } \\
\text { by email or in person }\end{array}$ & 32.9 & 35.8 & 39.2 & $33.704 * *$ \\
\hline $\begin{array}{l}\text { Students frequently interacted with faculty during } \\
\text { lecture class sessions }\end{array}$ & 19.4 & 19.9 & 23.9 & $32.406 * *$ \\
\hline
\end{tabular}


Table 1 continued

\begin{tabular}{|c|c|c|c|}
\hline \multirow[t]{2}{*}{ Type of interaction } & \multicolumn{3}{|l|}{ First-generation } \\
\hline & Non-first-generation & First-generation & Chi-square \\
\hline \multicolumn{4}{|l|}{ Research-related student-faculty interaction } \\
\hline Students assisted faculty research as a volunteer & 16.5 & 15.5 & 2.745 \\
\hline Students assisted faculty research for course credit & 20.5 & 17.7 & $20.206 * *$ \\
\hline Students assisted faculty research for pay & 11.3 & 11.0 & .446 \\
\hline \multicolumn{4}{|l|}{ Course-related student-faculty interaction } \\
\hline $\begin{array}{l}\text { Students frequently }{ }^{\mathrm{a}} \text { talked with faculty outside } \\
\text { of class about course material }\end{array}$ & 19.2 & 19.4 & 4.243 \\
\hline $\begin{array}{l}\text { Students frequently }{ }^{\mathrm{a}} \text { communicated with faculty } \\
\text { by email or in person }\end{array}$ & 37.2 & 33.6 & $13.463 *$ \\
\hline $\begin{array}{l}\text { Students frequently }{ }^{\mathrm{a}} \text { interacted with faculty } \\
\text { during lecture class sessions }\end{array}$ & 21.6 & 17.9 & $21.058 * *$ \\
\hline
\end{tabular}

Note: Sample sizes for student subgroups vary depending on the type of student-faculty interaction (refer to "Data Source and Sample" section for more information). For research-related student-faculty interaction, sample sizes for each subgroup are as follows: male $=12,682$; female $=17,820$; African American $=730$; Latino = 3,807; Asian American = 11,693; White = 11,180; lower-class = 3,168; middle-class = 16,744; upper-class $=8,188$; non-first-generation $=22,274$; first-generation $=5,214$. For course-related studentfaculty interaction, sample sizes for each subgroup are as follows: male $=4,345$; female $=6,488$; African American $=250$; Latino $=1,376$; Asian American $=4,404$; White $=3,825$; lower-class $=1,214$; middleclass $=6,338$; upper-class $=3,227$; non-first-generation $=7,987$; first-generation $=1,820$

${ }^{\text {a }}$ Frequently $=$ often or very often

$* p<.005 ; * * p<.0001$

\section{Differences in the Student Satisfaction with Faculty Contact by Student Characteristics}

Whereas the variation in the frequency of faculty contact by each student characteristic presented a mixed pattern depending on the forms of interaction, differences in student satisfaction with faculty contact demonstrated a clear pattern in each student characteristic. Table 2 depicts the results of the cross-tabulation analyses for student satisfaction with faculty contact by different student characteristics. Female and non-first-generation students were more satisfied with both advising by faculty on academic matters and access to faculty outside of class than male and first-generation students. White students reported the highest satisfaction with faculty contact, followed by Latinos, African Americans, and Asian Americans. The results also show that as social class rises, so does students' satisfaction with faculty interaction.

\section{Different Impact of Student-Faculty Interaction by Student Characteristics}

In order to comprehensively examine whether the relationship between student-faculty interaction and student educational outcomes varies by student gender, race, social class, and first-generation status, multiple sets of regression analyses were conducted. Across the different outcomes measures, the proportion of variance accounted for by the independent variables generally ranged from $20 \%$ to $50 \%$, except for a few notably low or high $R^{2}$. Overall, the $R^{2}$ were relatively higher for male, African American (regressions with course- 
Table 2 Level of student satisfaction with faculty contact by student subgroups

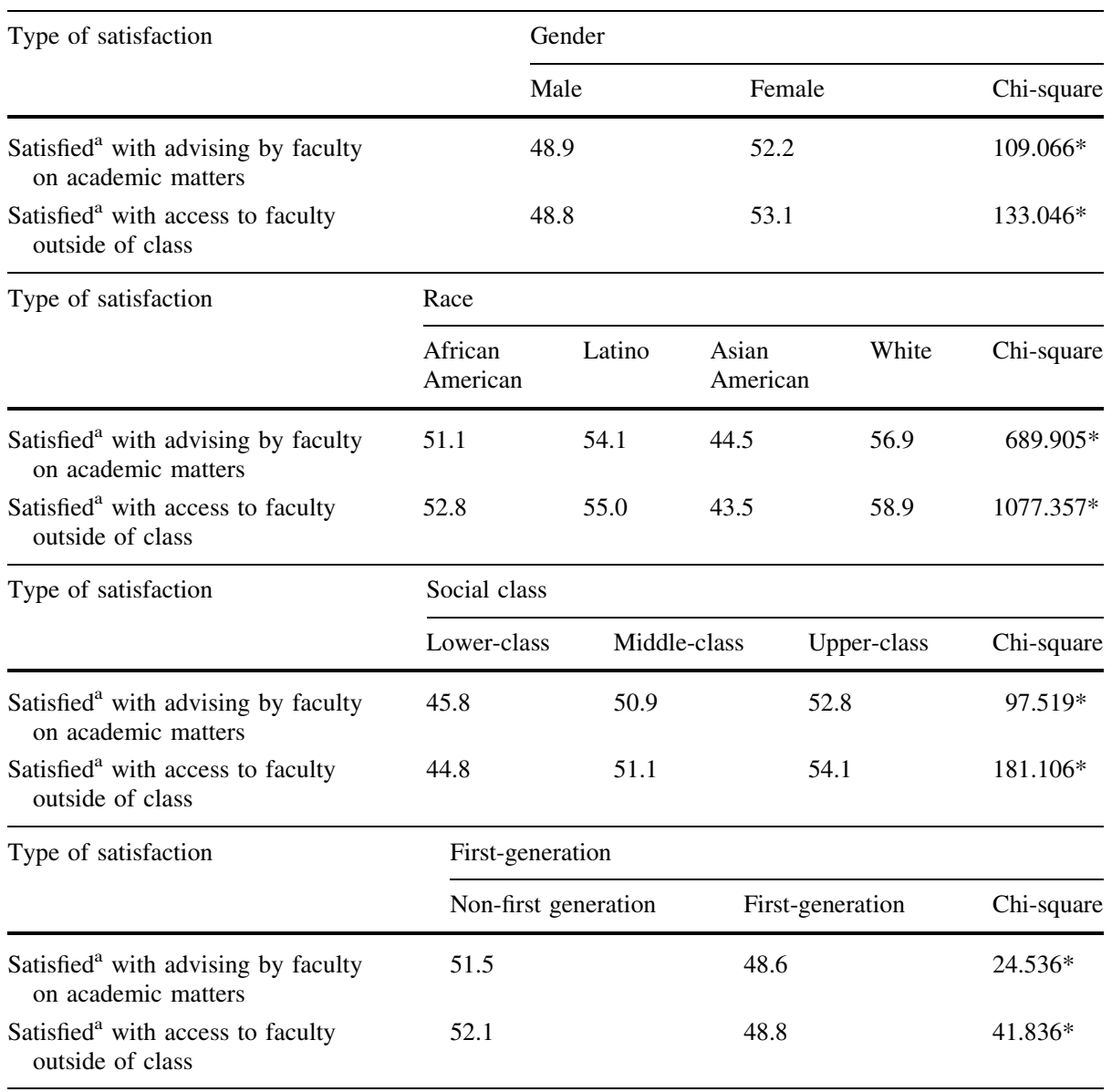

Note: Sample sizes for each subgroup are as follows: male $=12,682$; female $=17,820$; African American $=730 ;$ Latino $=3,807$; Asian American = 11,693; White $=11,180$; lower-class $=3,168$; middleclass $=16,744$; upper-class $=8,188$; non-first-generation $=22,274$; first-generation $=5,214$

${ }^{\text {a }}$ Satisfied $=$ satisfied or very satisfied

$* p<.0001$

related interaction only), lower-class, and first-generation (regressions with course-related interaction only) students than female, non-African American, middle- and upper-class, and non-first-generation counterparts. $R^{2}$ and $F$ change statistics also revealed that adding each independent variable block increased the amount of variance explained in student outcomes and these increases were statistically significant. The $R^{2}$ changes subsequent to the inclusion of the seventh block (i.e., student-faculty interaction measure) were generally small (around .01), which is not surprising given the large number of control variables used and the fact that the seventh block consisted of a single variable. Thus, the unique relationships between student-faculty interaction and college outcomes, though statistically significant, are generally modest in nature. 
Furthermore, to determine whether the relationships are significantly different for student subgroups, $t$-tests were also conducted. Results of $t$-tests were presented by the bolded regression coefficient and/or the letter that corresponds to the group whose effect is significantly different at the $p<.05$ level from the group compared. There existed complex dynamics in the relationships between student-faculty interactions and educational outcomes that depended on the type of faculty interaction, the specific student outcome, and the students' characteristics.

\section{Research-Related Student-Faculty Interaction}

Table 3 displays final standardized regression coefficients (betas) of research-related faculty interaction on six different types of student outcomes by student gender, race, social class, and first-generation status. The final regression coefficient indicates the unique predictive power of the independent variable (i.e., research-related faculty interaction) on the dependent variable (each of student outcomes) after controlling for the effects of other independent variables. Along with the regression coefficients, $t$-test results were also demonstrated with letters in parentheses to exhibit whether the differences in the coefficients across student subgroups are statistically significant.

Students' experience of assisting faculty with research as a volunteer, for course credit, or for pay (i.e., research-related faculty contact) significantly and positively predicted their higher college GPAs, higher degree aspirations, and larger gains in critical thinking and communication for both male and female students, and the effects are not significantly different between the two groups. In contrast, this type of faculty interaction increased the perception of belonging at the campus (i.e., integration) for female students only.

Differences in the relationships between research-related faculty contact and student outcomes among African American, Latino, Asian American, and White students revealed more mixed findings. Undergraduate research experience was significantly and positively associated with students' college GPA for all racial groups, but the association was stronger among African American students than for Latino and Asian American students. This experience also led all racial groups of students to aspire to higher academic degrees, but the positive effect was more pronounced for White students than Latino and Asian American students. Research-related faculty contact was positively related to perception of belonging at campus for White students only, and gains in critical thinking and communication for Latinos, Asian Americans, and Whites only. Interestingly, research-based faculty interaction tended to decrease Latino students' gains in cultural appreciation and social awareness. Perhaps in this case the research experience serves in place of other aspects of campus involvement that may more enhance cultural awareness, such as student clubs and groups.

The impact of research-related faculty interaction also demonstrated different patterns among lower-, middle-, and upper-class students. For all social class groups, students who assisted faculty with research were more likely to obtain higher college GPAs and aspire to higher degree attainments. However, the research experience had a significantly positive effect on student gains in critical thinking and communication for middle- and upper-class students only, and it had a slightly negative effect on middle-class students' gains in cultural appreciation and social awareness.

The positive impact of students' research experience with faculty on their college GPA, degree aspiration, and gains in critical thinking and communication was equally strong for both first-generation and non-first-generation college students. For students whose parents 
Table 3 Standardized regression coefficients of research-related student-faculty interaction on student outcomes by student subgroups

\begin{tabular}{|c|c|c|c|c|c|c|}
\hline \multirow[t]{2}{*}{ Student subgroups } & \multicolumn{6}{|c|}{ Student outcomes } \\
\hline & GPA & $\begin{array}{l}\text { Degree } \\
\text { aspiration }\end{array}$ & Integration & $\begin{array}{l}\text { Critical } \\
\text { thinking }\end{array}$ & $\begin{array}{l}\text { Social } \\
\text { awareness }\end{array}$ & Satisfaction \\
\hline \multicolumn{7}{|l|}{ Gender } \\
\hline Male & $.09 * * *$ & $.14 * * *$ & .00 & $.03 * *$ & -.02 & .00 \\
\hline Female & $.07 * * *$ & $.16 * * *$ & $.03 * *$ & $.03 * *$ & -.01 & .00 \\
\hline \multicolumn{7}{|l|}{ Race } \\
\hline AFA $[\mathrm{A}]$ & $.18 * * *(B, C)$ & $.19 * * *$ & -.04 & -.03 & -.08 & -.04 \\
\hline LAT $[\mathrm{B}]$ & $.06 * *$ (A) & $.12 * * *(D)$ & $-.01(\mathrm{D})$ & $.04 *$ & $-.04 *$ & -.02 \\
\hline ASA [C] & $.08 * * *(\mathrm{~A})$ & $.13 * * *(D)$ & .02 & $.02 *$ & -.01 & .00 \\
\hline WHI [D] & $.09 * * *$ & $.17 * * *(B, C)$ & $.03 *(\mathrm{~B})$ & $.04 * *$ & -.01 & .01 \\
\hline \multicolumn{7}{|l|}{ Social class } \\
\hline Lower & $.07 * *$ & $.14 * * *$ & -.02 & .03 & -.02 & -.01 \\
\hline Middle & $.07 * * *$ & $.14 * * *$ & .02 & $.02 *$ & $-.02 *$ & .00 \\
\hline Upper & $.10 * * *$ & $.17 * * *$ & .01 & $.04 *$ & -.01 & .01 \\
\hline \multicolumn{7}{|l|}{ First-generation } \\
\hline Non-first & $.08 * * *$ & $.16^{* * *}$ & $.02 *$ & $.03 * * *$ & $-.02 *$ & .01 \\
\hline First & $.08 * * *$ & $.14 * * *$ & -.01 & $.03 *$ & .00 & -.01 \\
\hline
\end{tabular}

Note 1: AFA African American; LAT Latino; ASA Asian American; WHI White

Note 2: Results of $t$-tests are presented by the bolded beta and/or the letter corresponding to the group whose effect is significantly different at the .05 level from the group compared

Note 3: Sample sizes for each subgroup are as follows: male $=12,682$; female $=17,820$; African American $=730 ;$ Latino $=3,807$; Asian American $=11,693$; White $=11,180$; lower-class $=3,168$; middleclass $=16,744$; upper-class $=8,188$; non-first-generation $=22,274$; first-generation $=5,214$

$* p<.05 ; * * p<.01 ; * * * p<.0001$

attended college, this type of interaction had a slightly positive effect on students' perception of belonging at campus. Interestingly, it had a significantly, but small, negative effect on non-first-generation college students' gains in social awareness. Similar to the interpretation noted above for Latino students and gains in social awareness, perhaps research-related faculty interaction detracts from non-first-generation college students' gains in social awareness whereas other involvement choices may enhance the gains.

\section{Course-Related Student-Faculty Interaction}

Table 4 displays final standardized regression coefficients (betas) of course-related faculty interaction on six different types of student outcomes by student gender, race, social class, and first-generation status. As shown in the table, course-related faculty contact (i.e., talking, communicating, or interacting with faculty) also revealed various patterns in its impact on the six student outcomes depending on different student characteristics. For both female and male students, course-related student-faculty interaction related to higher college GPAs, larger gains in critical thinking and communication, and greater satisfaction 
Table 4 Standardized regression coefficients of course-related student-faculty interaction on student outcomes by student subgroups

\begin{tabular}{|c|c|c|c|c|c|c|}
\hline \multirow{2}{*}{$\begin{array}{l}\text { Student } \\
\text { subgroups }\end{array}$} & \multicolumn{6}{|c|}{ Student outcomes } \\
\hline & GPA & $\begin{array}{l}\text { Degree } \\
\text { aspiration }\end{array}$ & Integration & $\begin{array}{l}\text { Critical } \\
\text { thinking }\end{array}$ & $\begin{array}{l}\text { Social } \\
\text { awareness }\end{array}$ & Satisfaction \\
\hline \multicolumn{7}{|l|}{ Gender } \\
\hline Male & $.14 * * *$ & $.18 * * *$ & $.13 * * *$ & $.11 * * *$ & $.06^{*}$ & $.12 * * *$ \\
\hline Female & $.14 * * *$ & $.09 * * *$ & .04 & $.06^{* *}$ & .00 & $.07 * *$ \\
\hline \multicolumn{7}{|l|}{ Race } \\
\hline AFA $[\mathrm{A}]$ & -.06 & -.12 & -.18 & -.10 & $-.29(\mathrm{~B}, \mathrm{C})$ & -.36 \\
\hline LAT [B] & $.12 *$ & .08 & .08 & $.10^{*}$ & $.10 *(\mathrm{~A})$ & $.13^{*}$ \\
\hline ASA $[C]$ & $.08 * *$ & $.13^{* * *}$ & $.11 * * *$ & $.11 * * *$ & $.09^{* *}(\mathrm{~A}, \mathrm{D})$ & $.11 * * *$ \\
\hline WHI [D] & $.16^{* * *}$ & $.14 * * *$ & $.09^{* *}$ & .05 & $.01(\mathrm{C})$ & $.10^{* *}$ \\
\hline \multicolumn{7}{|l|}{ Social class } \\
\hline Lower [L] & $.14 * *$ & $.14 *$ & .08 & $.11 *$ & $.11^{*}$ & $.20 * * *$ \\
\hline Middle [M] & $.12 * * *$ & $.13^{* * *}$ & $.10 * * *$ & $.07^{* *}$ & .03 & $.09 * * *(\mathbf{U})$ \\
\hline Upper [U] & $.18 * * *$ & $.13^{* * *}$ & .03 & $.08^{* *}$ & .00 & $.18^{* * * *}(\mathrm{M})$ \\
\hline \multicolumn{7}{|l|}{ First-generation } \\
\hline Non-first & $.16^{* * * *}$ & $.12^{* * * *}$ & $.08^{* * * *}$ & $.08^{* * *}$ & .02 & $.13 * * *$ \\
\hline First & .07 & $.11 *$ & $.10^{*}$ & $.10^{* *}$ & .08 & $.18 * * *$ \\
\hline
\end{tabular}

Note 1: AFA African American; LAT Latino; ASA Asian American; WHI White

Note 2: Results of $t$-tests are presented by the bolded beta and/or the letter corresponding to the group whose effect is significantly different at the .05 level from the group compared

Note 3: Sample sizes for each subgroup are as follows: male $=4,345$; female $=6,488$; African American $=250 ;$ Latino $=1,376$; Asian American $=4,404$; White $=3,825$; lower-class $=1,214$; middleclass $=6,338$; upper-class $=3,227$; non-first-generation $=7,987$; first-generation $=1,820$

$* p<.05 ; * * p<.01 ; * * * p<.0001$

with overall college experience. This form of faculty contact was also positively associated with student degree aspiration for both males and females, but the association was significantly stronger for male students. The positive effect of course-related student-faculty interaction on student integration and gains in social awareness were exclusively significant for male students.

Turning now to differences across racial groups, the effect of course-related studentfaculty interaction on college GPA and overall college satisfaction was significant and positive for all groups except African Americans. Comparatively, this type of faculty interaction had a positive impact on student degree aspiration and integration for Asian American and White students only. The results also indicate that course-related faculty contact served to positively predict gains in critical thinking as well as social awareness for Latino and Asian American students, but it did not for African American and White students.

Course-related faculty interaction led all students of all social class levels to obtain higher college GPAs, aspire to more advanced degrees, achieve larger gains in critical thinking and communication, and be more satisfied with overall college experience. However, the positive impact of this contact on student overall satisfaction was significantly stronger for upper-class students than middle-class students. Course-related faculty 
interaction related to a stronger sense of belonging at the campus for middle-class students only, and larger gains in cultural appreciation and social awareness for lower-class students only.

Patterns in the impact of faculty interaction dependent on first-generation status were simpler and more straightforward than gender, racial, and social class differences. In many cases, the effects of student-faculty interaction were significant and positive for both firstand non-first- generation students. Also, there was no statistical difference in the effects of student-faculty interaction on educational outcomes between the two student subgroups, although the regression coefficients slightly varied depending on students' first-generation status. Course-related faculty interaction significantly and positively predicted students' degree aspiration, sense of belonging on campus, gains in critical thinking and communication, and overall college satisfaction regardless of students' first-generation status. This interaction served to improve college GPA for students whose parents attended college, while it did not for students whose parents have not attended college.

\section{Limitations}

Although this study contributes to the existing literature by revealing conditional effects of student-faculty interaction based on various student characteristics, the study is limited in several respects. Perhaps the greatest limitation in the present study is its lack of reliance on longitudinal data. Since the survey used in this study has simultaneously measured student college experiences and educational outcomes, it does not inform researchers of any time sequencing between the variables. Thus, the results from this study should be interpreted as correlational connections rather than causal connections, although traditional college impact models—such as Astin's (1991) I-E-O framework, or Tinto's (1987) departure model-have shared the common assumption that college experience in general, and student-faculty interaction in particular, affects student outcomes. Ideally, future study would include measures of degree aspirations, critical thinking and other skills before students attended college. That way, we could assess, for example, whether and how interactions with faculty make a difference in students' degree aspirations, critical thinking, and cultural awareness. Thus, while we talk in terms of "effects" of student-faculty interaction, data collected at multiple time points would improve our ability to make causal inferences. Next, small sub-sample size is another limitation of this study, especially for African American students. Since this racial group was severely underrepresented $3.0 \%$ of the full sample), some regression analyses for the group may be less reliable than for the larger subgroup samples. Another limitation is that the factor scale of research-related interaction has a somewhat low internal consistency (Cronbach's alpha $=.60$ ). This is mainly because the composite measure was constructed by aggregating three dichotomous variables regarding faculty contact. To overcome this limitation, future research with these data ought to utilize a dichotomous variable that captures student's general research-related faculty contact from the three variables instead of summing up them.

\section{Summary and Discussion}

Set in the context of a large and diverse research university system, this study examines the impact of research-related and course-related student-faculty interaction across six student outcomes, and how the effects of such interaction vary by student's gender, race, social 
class, and first-generation status. As noted earlier, research on the role played by studentfaculty interactions has been limited due to a reliance on aggregated samples of students, such that general effects are well-documented but conditional effects are relatively unknown. As college campuses become increasingly diverse, especially when it comes to race and socioeconomic status, our understanding of the role played by student involvement with faculty cannot rely solely on prior research. It is possible that aspects of studentfaculty interaction may be more or less beneficial for some groups than others, a fact demonstrated by Sax et al. (2005) with respect to gender and Kim (2006) with respect to race.

The results of this study do suggest some conditional effects across some outcomes. Student characteristics such as gender, race, and social class seem to shape the nature of the relationship between student-faculty interactions and developmental outcomes. While course-related faculty interaction led both genders to aspire to more advanced academic degrees, this positive relationship was more pronounced among male students. That is, talking, communicating, or interacting with faculty regarding course-related issues promotes higher degree aspiration for both male and female students, but the relationship is stronger for male students than females. With regard to race-based patterns, two conditional effects were observed in the relationship between research-related faculty interaction and two outcomes: college GPA and degree aspiration. Undergraduate research experience was significantly and positively associated with students' college GPA for all racial groups of students, but the relationship was notably stronger among African American students than Latino and Asian American students. This experience also predicted higher degree aspiration for all racial groups, but the effect was more pronounced for White students than for Latino and Asian American students. Differences across social class were apparent in the effects of course-related faculty contact on student satisfaction. While the relationship between course-related interaction and student's overall satisfaction with college experience was positive for all social class categories, the association was significantly stronger for upper-class students than middle-class students.

This demonstration of conditional effects better explains how certain student subgroups benefit more or less as a result of student-faculty interaction, by revealing the complex dynamics between faculty interactions and outcomes that general effects cannot show. For example, as a result of course-related faculty contact, male students may receive greater benefits related to degree aspiration than female students. This study also suggests that research-related faculty interactions provide unique benefits to African American students in terms of college GPA, and to White students in terms of degree aspirations. Likewise, upper-class students benefit more than middle-class students from course-related faculty contact with regard to college satisfaction.

Though this study has placed emphasis on the study of conditional effects, it also reveals numerous general effects of student-faculty interactions (i.e., effects that generally do not vary by gender, race, social class, or first-generation status). These are listed below, along with notable exceptions in parentheses:

- Research-related faculty interaction predicts higher college GPAs for all groups;

- Research-related faculty interaction promotes degree aspirations for all groups;

- Research-related faculty interaction enhances critical thinking and communication for all groups (except African Americans and lower-class students);

- Course-related faculty interaction predicts higher college GPAs for all groups (except African Americans and first-generation students); 
- Course-related faculty interaction promotes degree aspirations for all groups (except African Americans and Latinos);

- Course-related faculty interaction enhances critical thinking and communication for all groups (except African Americans and Whites); and

- Course-related faculty interaction enhances satisfaction for all groups (except African Americans).

The descriptive analyses presented in this study also document important patterns in students' frequency of and satisfaction with faculty interaction that depend on student gender, race, social class, or first-generation status. The patterns are as follows:

- Female students tend to prefer to interact with faculty one-on-one (i.e., communication with faculty by email or in person) rather than in public or group settings (i.e., interaction with faculty during lecture class sessions);

- Asian American students are more likely than other racial groups to be involved in undergraduate research experience, but they are least likely to interact with faculty regarding course-related issues;

- African American students tend to interact more frequently with their faculty for course-related matters than other racial groups, whereas they are least likely to assist faculty with research;

- Upper-class students are more likely than other students to assist faculty with research for course credit, while lower-class students are most likely to do so for pay;

- As student's social class gets higher, so does frequency of communicating or interacting with faculty;

- First-generation college students tend to less frequently assist faculty with research for course credit, communicate with faculty outside of class, and interact with faculty during lecture class sessions than non-first-generation students; and

- Females, Whites, upper-class students, and non-first-generation are more satisfied with their interaction with faculty than their male, non-White, lower-class and firstgeneration counterparts.

Of the descriptive findings, race-based patterns of faculty contact are worth noting. Previous college impact research has demonstrated general patterns that Asian American students experience less frequent student-faculty interaction than their peers, while African Americans report the highest frequency of interaction (Chang 2005; Cole 2006; Kim et al. 2006; Kuh and Hu 2001; Lundberg and Schreiner 2004). However, the findings from this study suggest that this race-based pattern also may vary depending on the type of faculty contact. That is, contrary to prevailing findings from literature, Asian American students exceeded all other racial groups of students in research-related faculty interaction, while they documented the lowest frequency of course-related interaction (the latter consistent with previous findings). Likewise, African American students were least likely to be involved in research-related faculty contact, although they reported the highest frequency of course-related faculty interaction in common with literature (the latter consistent with prior research).

\section{Implications for Practice}

From the findings of this study, conditional effects of student-faculty interaction (i.e., effects that vary across different student subgroups) as well as descriptive patterns in faculty interaction were observed based on different student characteristics such as gender, 
race, social class, and first-generation status. The findings provide institutions and their members with significant implications for educational practice on how to maximize the educational efficacy of student-faculty interaction by minimizing the gender, race, social class, and first-generation differences associated with it.

Faculty members, administrators, and student affairs professionals should pay particular attention to underrepresented student groups in terms of benefits of student-faculty interaction. It is clear from the demonstration of conditional effects that certain student subgroups benefit more or less as a result of student-faculty interaction. For example, while both genders and all racial groups benefit from course- and research-related faculty contact, respectively, with regard to degree aspiration, male and White students tend to receive greater benefits than female and non-White students. This finding indicates that during interaction with students, faculty members may be inclined to provide greater motivation and encouragement to go to graduate schools for male and White students than they do for females and non-White students. Based on the type of interaction where the conditional effects were detected, the finding suggests that faculty members ought to be more purposeful in discussing graduate education when they interact or communicate with female students inside or outside of class. Likewise, when conducting research in cooperation with students, faculty should make an effort to discuss pathways to graduate school with African American, Asian American, and Latino students to the same extent as they do for White students.

Descriptive patterns in faculty interaction presented by the current study also have practical implications for educational settings in higher education. The study indicates that types of faculty interaction preferred or disfavored by students vary depending on student gender, race, social class, and first-generation status. Thus, strategies to enhance studentfaculty interaction may not be equally effective for all student subgroups. Rather, faculty and student affairs professionals should formulate and apply different strategies to each student subgroups, based on their unique patterns in experiencing faculty contact. For example, in order to mitigate gender gaps in the frequency of student-faculty interaction, faculty could encourage female students to engage more in discussion and activity during class sessions. With regard to racial gaps, faculty should invite more African American students to work on their research projects, so that the student population can achieve a proper balance between course- and research-related interaction. Faculty should also take note of the findings that Asian American students are less likely than other racial groups to talk, communicate, or interact with faculty both inside and outside of class, and that language heritage may be a unique barrier to faculty interaction for this population (Kim et al. 2006). Accordingly, when faculty communicate or interact with Asian American students, they should keep in mind the group's unique characteristics and try to apply diverse strategies to make themselves more approachable and sympathetic to Asian American students (e.g., individual rather than group meetings, outside rather than inside class contact, email rather than oral communication). Finally, the findings from the present study reveal that compared to middle- or upper-class or non-first generation students, lower-class and first-generation students generally are more often excluded from faculty interaction whether it is research-related or course-related. Revealing different patterns in faculty interaction that depend on student's social class and first-generation status, these findings suggest another potential area where further study is needed by college impact researchers and more attention by faculty and student affairs professionals. That is, institutions and their members as well as higher education scholars need to know more about how lower-class and first-generation students experience faculty contact differently from their counterparts. 
Although this study has mainly focused on the examination of conditional effects, it also reveals numerous general effects of student-faculty interaction (i.e., effects that generally do not vary across different student subgroups) on multiple student educational outcomes. This finding confirms again the fact that in many areas, interacting with faculty improves student's learning and development regardless of student gender, race, social class, and first-generation status. Consequently, institutions and their members (i.e., administrators and student affairs professionals as well as faculty and students) should continue making an effort to create environments where positive and meaningful interactions between students and their faculty can occur.

\section{Conclusion and Future Directions}

While the general positive effects generated by student-faculty interaction are well-documented, little is known about how various student subgroups experience the interaction differently. This study furthers our understanding of it by uncovering gender, racial, and social class differences in the impact of student-faculty interaction across undergraduate student outcomes, though it reveals no such differences by first-generation status. It justifies the study of conditional effects of student-faculty interaction in particular, and furthermore extends the traditional view concerning the effects of college experiences on student outcomes in general. It is evident from the findings of this study that a "one size fits all" student development model does not adequately capture the unique experience of various student subgroups.

Given the conditional effects and descriptive patterns in faculty interaction detected in this study, the next step should be to understand the context for these differences. For example, we may extend the current study by examining student characteristics or college environments that explain both the lower or higher levels of faculty interaction and differential benefits of the interaction for certain student subgroups. Our understanding of the underlying dynamics requires additional data, and would benefit most from interviews and observations that focus more specifically on the nature and context of the student-faculty relationship across different student subgroups. Also, further research may utilize experimental (which includes control and treatment groups) or multi-wave longitudinal (which includes pre- and post-test measures) data to assess more thoroughly whether and how faculty interaction make a difference in student educational outcomes. Finally, future research should assess whether the conditional effects of student-faculty interaction identified here are applicable across different type of institutions (e.g., public/private, 4year/2-year, research university/liberal arts college) as well as whether other student characteristics beyond those identified here serve to shape the nature and impact of students' interactions with their professors.

Open Access This article is distributed under the terms of the Creative Commons Attribution Noncommercial License which permits any noncommercial use, distribution, and reproduction in any medium, provided the original author(s) and source are credited. 


\section{Appendices}

See Tables 5, 6, and 7 .

Table 5 Outcome measures

\begin{tabular}{|c|c|c|c|}
\hline Outcome measure & Survey item & Mean & $\begin{array}{l}\text { Standard } \\
\text { deviation }\end{array}$ \\
\hline College GPA & $\mathrm{UC} \mathrm{GPA}^{\mathrm{a}}$ & 3.03 & .53 \\
\hline Degree aspiration & Highest degree planned $^{\mathrm{b}}$ & 1.95 & .68 \\
\hline Integration & $\begin{array}{l}\text { Factor }(\alpha=.83)^{\mathrm{c}} \\
\text { Feeing that I belong at this campus } \\
\text { Intention to still choose to enroll at this } \\
\text { campus }\end{array}$ & 4.57 & 1.22 \\
\hline $\begin{array}{l}\text { Gains in critical thinking } \\
\text { and communication }\end{array}$ & $\begin{array}{l}\text { Factor }(\alpha=.91)^{\mathrm{d}} \\
\text { Analytical and critical thinking skills } \\
\text { Ability to be clear and effective when } \\
\text { writing } \\
\text { Ability to read and comprehend } \\
\text { academic material } \\
\text { Understanding of a specific field of study } \\
\text { Ability to speak clearly and effectively } \\
\text { in English } \\
\text { Understanding international perspectives } \\
\text { Leadership skills } \\
\text { Computer skills } \\
\text { Internet skills } \\
\text { Library search skills } \\
\text { Other research skills } \\
\text { Ability to prepare and make a presentation }\end{array}$ & 4.98 & 1.89 \\
\hline $\begin{array}{l}\text { Gains in cultural appreciation } \\
\text { and social awareness }\end{array}$ & $\begin{array}{l}\text { Factor }(\alpha=.87)^{\mathrm{d}} \\
\text { Interpersonal skills } \\
\text { Ability to appreciate, tolerate, and understand racial } \\
\text { and ethnic diversity } \\
\text { Ability to appreciate the fine arts } \\
\text { Ability to appreciate cultural and global } \\
\text { diversity } \\
\text { Understanding the importance of personal } \\
\text { social responsibility } \\
\text { Self awareness and understanding }\end{array}$ & 4.98 & 1.87 \\
\hline $\begin{array}{l}\text { Satisfaction with overall college } \\
\text { experience }\end{array}$ & $\begin{array}{l}\text { Factor }(\alpha=.85)^{\mathrm{e}} \\
\text { Satisfaction with overall academic experience } \\
\text { Satisfaction with overall social experience }\end{array}$ & 4.31 & 1.02 \\
\hline
\end{tabular}

${ }^{\mathrm{a}}$ UC GPA refers to GPA reported in UC system student records and ranged from .00 to 4.00

b Three-point scale: $1=$ Bachelor's degree to $3=$ Doctorate and more

c All individual variables included in the factor have six-point scale, ranging from $1=$ strongly disagree to $6=$ strongly agree

d The factors were developed by Center for Studies in Higher Education (CSHE), UC Berkeley in 2006 . All individual variables included in the factor have six-point scale, ranging from $1=$ very poor to $6=$ excellent

e All individual variables included in the factor have six-point scale, ranging from 1 = very dissatisfied to $6=$ very satisfied 
Table 6 Student-faculty interaction measures

\begin{tabular}{|c|c|c|c|c|}
\hline Measures & $\begin{array}{l}\text { Factor } \\
\text { loading }\end{array}$ & $\begin{array}{l}\text { Internal } \\
\text { consistency } \\
\text { (Alpha) }\end{array}$ & Mean & $\begin{array}{l}\text { Standard } \\
\text { deviation }\end{array}$ \\
\hline Research-related student-faculty interaction ${ }^{a}$ & & .60 & .16 & .26 \\
\hline Students assisted faculty with research as a volunteer & .78 & & & \\
\hline Students assisted faculty with research for course credit & .75 & & & \\
\hline Students assisted faculty with research for pay & .71 & & & \\
\hline Course-related student-faculty interaction ${ }^{\mathrm{b}}$ & & .83 & 3.40 & 1.24 \\
\hline $\begin{array}{l}\text { Students talked with faculty outside of class about } \\
\text { course material }\end{array}$ & .82 & & & \\
\hline $\begin{array}{l}\text { Students communicated with faculty by email or in } \\
\text { person }\end{array}$ & .80 & & & \\
\hline $\begin{array}{l}\text { Students interacted with faculty during lecture class } \\
\text { sessions }\end{array}$ & .79 & & & \\
\hline
\end{tabular}

${ }^{a}$ For all individual variables included in the factor, dichotomous measures were used

b All individual variables included in the factor have six-point scale, ranging from $1=$ never to $6=$ very often

Table 7 Coding schemes and descriptive statistics for control variables

\begin{tabular}{|c|c|c|c|}
\hline Variable & Coding scheme & Mean & $\begin{array}{l}\text { Standard } \\
\text { deviation }\end{array}$ \\
\hline \multicolumn{4}{|l|}{ Demographic characteristics } \\
\hline Gender: Female & Dichotomous: $0=$ no, $1=$ yes & .54 & .49 \\
\hline \multicolumn{4}{|l|}{ Race } \\
\hline African American & All dichotomous: $0=$ no, $1=$ yes & .03 & .17 \\
\hline Asian American & & .38 & .49 \\
\hline Latino & & .14 & .35 \\
\hline White & & .35 & .48 \\
\hline Age & Range from 16 to 73 & 20.29 & 2.96 \\
\hline Mother's educational level & $\begin{array}{l}\text { Nine-point scale: } 1=\text { less than high school to } \\
9=\text { doctorate }\end{array}$ & 5.43 & 2.27 \\
\hline Father's educational level & $\begin{array}{l}\text { Nine-point scale: } 1=\text { less than high school to } \\
9=\text { doctorate }\end{array}$ & 5.75 & 2.32 \\
\hline Total parental annual income & $\begin{array}{l}\text { Eleven-point scale: } 1=\text { less than } 10,000 \text { to } \\
11=200,000 \text { or more }\end{array}$ & 6.20 & 2.81 \\
\hline Born or came to US & $\begin{array}{l}\text { Sixteen-point scale: } 1=\text { born in US to } \\
16=\text { came to US } 2005 \text { or later }\end{array}$ & 2.12 & 2.91 \\
\hline $\begin{array}{l}\text { Language heritage (when learn } \\
\text { to speak English) }\end{array}$ & $\begin{array}{l}\text { Five-point scale: } 1=\text { native English to } \\
5=\text { after turning } 16 \text { years old }\end{array}$ & 1.60 & .95 \\
\hline \multicolumn{4}{|l|}{ Initial freshman year experiences } \\
\hline Transfer status & Dichotomous: $0=$ no, $1=$ yes & .21 & .40 \\
\hline Student level & Four-point scale: $1=$ freshman to $4=$ senior & 2.80 & 1.10 \\
\hline Term of entry: Fall & Dichotomous: $0=$ no, $1=$ yes & .94 & .23 \\
\hline
\end{tabular}


Table 7 continued

\begin{tabular}{|c|c|c|c|}
\hline Variable & Coding scheme & Mean & $\begin{array}{l}\text { Standard } \\
\text { deviation }\end{array}$ \\
\hline
\end{tabular}

Institutional characteristics

Current institution

Berkeley
Davis
Irvine
Los Angeles
Merced
Riverside
San Diego
Santa Barbara
Santa Cruz

All dichotomous: $0=$ no, $1=$ yes $\begin{array}{cc}.14 & .35 \\ .14 & .34 \\ .12 & .33 \\ .15 & .36 \\ .01 & .07 \\ .09 & .28 \\ .13 & .33 \\ .11 & .31 \\ .08 & .27\end{array}$

Student major field

Arts and Humanities

All dichotomous: $0=$ no, $1=$ yes

$.32 \quad .46$

Biological and Physical Science

Business

$.04 \quad .20$

Professional

$.01 \quad .13$

Engineering

Social Science

$.11 \quad .31$

Other majors

$.19 \quad .39$

$.09 \quad .29$

Major field climate

Major field climate: Open
channels of communication b/w

Dichotomous: $0=$ no, $1=$ yes faculty and students

Major field climate: Students

Dichotomous: $0=$ no, $1=$ yes treated equitably and fairly by faculty

College experiences

Total UC units completed

Range from 0 to 494

$120.97 \quad 57.72$

Curricular foundations for

Factor $^{\mathrm{a}}$ reasoning

Factor $^{\mathrm{a}}$

$4.99 \quad 2.00$

Elevated academic effort

Factor $^{\mathrm{a}}$

$5.00 \quad 1.99$

Collaborative learning

Factor $^{\mathrm{a}}$

$4.97 \quad 1.94$

Time employed

Factor $^{a}$

$4.98 \quad 1.89$

Academic time

Factor $^{\mathrm{a}}$

$2.96 \quad 1.68$

Library use

Five-point scale: $1=0$ to $5=4$ or more

$1.36 \quad .82$

Number of service learning courses

\footnotetext{
${ }^{a}$ Factor scales developed by Center for Studies in Higher Education, UC Berkeley
} 


\section{References}

Ancis, J. R., Sedlacek, W. E., \& Mohr, J. J. (2000). Student perceptions of campus cultural climate by race. Journal of Counseling and Development, 78, 180-185.

Astin, A. W. (1977). Four critical years: Effects of college on beliefs, attitudes, and knowledge. San Francisco: Jossey-Bass.

Astin, A. W. (1984). Student involvement: A developmental theory for higher education. Journal of College Student Personnel, 25(3), 297-308.

Astin, A. W. (1991). Assessment for excellence: The philosophy and practice of assessment and evaluation in higher education. New York: American Council on Education/Macmillan Publishing Company.

Astin, A. W. (1993). What matters in college? Four critical years revisited. San Francisco: Jossey-Bass.

Astin, A. W., \& Chang, M. J. (1995). Colleges that emphasize research and teaching: Can you have your cake and eat it too? Change, 27(5), 44-49.

Astin, A. W., \& Holland, J. L. (1961). The environmental assessment technique: A way to measure college environments. Journal of Educational Psychology, 52, 308-316.

Billson, J. M., \& Terry, M. B. (1982). In search of the silken purse: Factors in attrition among firstgeneration students. College and University, 58, 57-75.

Boyer Commission on Educating Undergraduates in the Research University. (1998). Reinventing undergraduate education: A blueprint for America's research universities. Stony Brook, NY: Carnegie Foundation for the Advancement of Teaching.

Cabrera, A. F., Colbeck, C. L., \& Terenzini, P. T. (2001). Developing performance indicators for assessing classroom teaching practices and student learning: The case of Engineering. Research in Higher Education, 42(3), 327-352.

Campbell, T. A., \& Campbell, D. E. (1997). Faculty/student mentor program: Effects on academic performance and retention. Research in Higher Education, 38(6), 727-742.

Chang, J. (2005). Faculty-student interaction at the community college: A focus on students of color. Research in Higher Education, 46(7), 769-802.

Colbeck, C. L., Cabrera, A. F., \& Terenzini, P. T. (2001). Learning professional confidence: Linking teaching practices, students' self-perceptions, and gender. The Review of Higher Education, 24(2), 173-191.

Cole, D. (2004, November). Minority students' faculty contact and the impact on their GPA. Paper presented at the annual meeting of the Association for the Study of Higher Education, Kansas City, MO.

Cole, D. (2006). Do interracial interactions matter? An examination of student-faculty contact and intellectual self-concept. The Journal of Higher Education, 78(3), 249-281.

Endo, J., \& Harpel, R. (1982). The effect of student-faculty interaction on students' educational outcomes. Research in Higher Education, 16(2), 115-138.

Garson, G. D. (2008). Multiple regression, North Carolina State University, Raleigh, NC. Retrieved March 17, 2008, from http://www2.chass.ncsu.edu/garson/PA765/regress.htm.

Hurtado, S. (1992). The campus racial climate: Contexts of conflict. The Journal of Higher Education, 63, 539-569.

Hurtado, S., Carter, D. F., \& Spuler, A. (1996). Latino student transition to college: Assessing difficulties and factors in successful college adjustment. Research in Higher Education, 37, 135-157.

Ishiyama, J. (2002). Does early participation in undergraduate research benefit social science and humanities students? College Student Journal, 36, 380-386.

Kezar, A., \& Moriarty, D. (2000). Expanding our understanding of student leadership development: A study exploring gender and ethnic identity. Journal of College Student Development, 41(1), 55-69.

Kim, Y. K. (2006). Student-faculty interaction in college: Examining its causalities, predictors, and racial differences. Unpublished doctoral dissertation. University of California, Los Angeles.

Kim, Y. K., Park, J. J., \& Chang, M. J. (2006, April). Asian American students and student-faculty interaction: Examining lower levels. Paper presented at the annual meeting of the American Educational Researcher Association, San Francisco, CA.

Kuh, G. D. (1995). The other curriculum: Out-of-class experiences associated with student learning and personal development. The Journal of Higher Education, 66(2), 123-155.

Kuh, G. D., \& Hu, S. (2001). The effects of student-faculty interaction in the 1990s. The Review of Higher Education, 24(3), 309-332.

Kuh, G. D., \& Vesper, N. (1997). A comparison of student experiences with good practices in undergraduate education between 1990 and 1994. The Review of Higher Education, 21(1), 43-61.

Lamport, M. A. (1993). Student-faculty informal interaction and the effect on college student outcomes: A review of the literature. Adolescence, 28, 971-990. 
Lau, L. K. (2003). Institutional factors affecting student retention. Education, 124(1), 126-136.

Lundberg, C. A., \& Schreiner, L. A. (2004). Quality and frequency of faculty-student interaction as predictors of learning: An analysis by student race/ethnicity. Journal of College Student Development, 45(5), 549-565.

Pascarella, E. T. (1980). Student-faculty informal contact and college outcomes. Review of Educational Research, 50(4), 545-595.

Pascarella, E. T. (1985). Students' affective development within the college environment. The Journal of Higher Education, 56(6), 640-663.

Pascarella, E. T. (2006). How college affects students: Ten directions for future research. Journal of College Student Development, 47(5), 508-520.

Pascarella, E. T., \& Terenzini, P. T. (1976). Informal interaction with faculty and freshman ratings of academic and nonacademic experience of college. Journal of Educational Research, 70, 35-41.

Pascarella, E. T., \& Terenzini, P. T. (2005). How college affects students (Volume 2): A third decade of research. San Francisco, CA: Jossey-Bass.

Sax, L. J., Bryant, A. N., \& Harper, C. E. (2005). The differential effects of student-faculty interaction on college outcomes for women and men. Journal of College Student Development, 46(6), 642-659.

Smart, J. C., Feldman, K. A., \& Ethnington, C. A. (2000). Academic discipline: Holland's theory and the study of college students and faculty. Nashville: Vanderbilt University Press.

Strauss, L. C., \& Terenzini, P. T. (2007). The effects of students in- and out-of-class experiences on their analytical and group skills: A study of Engineering Education. Research in Higher Education, 48(8), 967-992.

Terenzini, P. T., Pascarella, E. T., \& Blimling, G. S. (1999). Students' out-of-class experiences and their influence on learning and cognitive development: A literature review. Journal of College Student Development, 40, 610-622.

Thompson, M. D. (2001). Informal student-faculty interaction: Its relationship to educational gains in Science and Mathematics among community college students. Community College Review, 29(1), $35-57$.

Tinto, V. (1987). Leaving college: Rethinking the causes and curses of student attrition. Chicago, IL: University of Chicago Press.

Tinto, V. (1993). Leaving college: Rethinking the causes and curses of student attrition (2nd ed.). Chicago, IL: University of Chicago Press.

Volkwein, J. F., King, M. C., \& Terenzini, P. T. (1986). Student-faculty relationships and intellectual growth among transfer students. The Journal of Higher Education, 57(4), 413-430.

Weidman, J. (1989). Undergraduate socialization: A conceptual approach. In J. Smart (Ed.), Higher education: Handbook of theory and research (Vol. 5). New York: Agathon Press. 